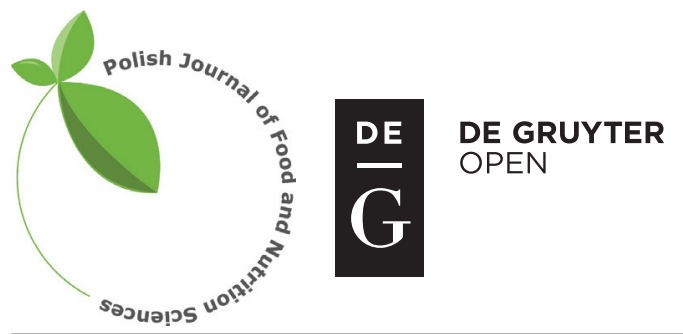

Pol. J. Food Nutr. Sci., 2016, Vol. 66, No. 1, pp. 17-23

DOI: $10.1515 /$ pjfns-2015-0013 http://journal.pan.olsztyn.pl

Original article

Section: Food Technology

\title{
Detection of Mechanically Recovered Poultry Meat (MRPM) in Traditional Egyptian Luncheon (Emulsion Type Sausage)
}

\author{
Mai A. Mohamed ${ }^{1}$, Dalia A. Zahran ${ }^{2 *}$, Gehan M.A. Kassem ${ }^{1}$, M.M.T. Emara ${ }^{1}$, N.M. Mansour ${ }^{1}$ \\ ${ }^{1}$ Food Hygiene Department, Faculty of Veterinary Medicine, Cairo University, Egypt \\ ${ }^{2}$ Health Radiation Research Department, National Center for Radiation Research and Technology (NCRRT), \\ P.O. Box: 29 Nasr City, Cairo, Egypt
}

Key words: MRPM, Egyptian luncheon, calcium, bone and cartilage

Detection of MRPM in emulsion type products is a challenge facing meat industry. Where, most of meat products processors in Egypt illegally replace beef meat partially or totally with MRPM in meat products to reduce products cost. Commercial and experimentally produced emulsion type sausage (traditional Egyptian luncheon) formulated with 0, 10, 30, 50, 70, 90\% MRPM instead of the meat mass and cooked to different core temperature $\left(70,80\right.$ and $\left.90^{\circ} \mathrm{C}\right)$ were examined for technological properties, ash, bones, cartilage and calcium $(\mathrm{Ca})$ content, in addition to histological sections stained with H\&E and Trichrome blue. Results indicated that all market samples showed unacceptable texture and binding scores with high ash, collagen, cartilage, bone and $\mathrm{Ca}$ content. Histological section showed the presence of skin and cartilage. Addition of 10\% MRPM to luncheon formulation could not be detected at different cooking temperatures. While the use of $30 \%$ or more MRPM to luncheon formulation, significantly changed technological properties and chemical composition of the product. Thermal treatments of luncheon sausages changed their chemical composition as well as induced structural changes in bone and cartilage content.

\section{INTRODUCTION}

Emulsion type sausages are widely used in the production of meat products such as bologna, frankfurter as well as different types of sausages [Dingman et al., 2002]. Traditional Egyptian luncheon is one of the most common emulsion type product in Egypt. The legal requirements of this type of sausage are established by Egyptian Standard Specification [ESS, 2005/1114], where moisture, protein, fat and ash contents are $60,15,30$ and $3 \%$, respectively. Meat emulsions are one of the most expensive meat products because their price depends mainly on high cost of lean meat. Consequently, most processors replace high quality and expensive meat by lower quality and cheaper materials such as mechanically recovered poultry meat (MRPM), used as a cheaper fat and collagen source in production of different meat products [Tyburcy et al., 2005].

Mechanically recovered meat means removal of any remnant flesh from bone after manual deboning. It was developed in Japan at 1950 for the fish industry and extended to the poultry industry as a result of increase poultry production [Field, 2004]. The end product of mechanical deboning process of poultry (MRPM) is pasty in nature, with good binding capacity [Serdaroğlu et al., 2005]. MRPM is used as an inexpensive product, with good nutritional and techno-

\footnotetext{
* Corresponding Author: E-mail: salmar_yasser@yahoo.com meat to be substituted by mechanically recovered meat in pro-

logical properties which encouraged most meat processor to substitute meat partially or totally by MRPM in most meat and poultry products such as emulsion products e.g. as frankfurter and formed products e.g. burger due to its easy incorporation in these products [Benitez et al., 2002; Serdaroğlu et al., 2005]. Nutritional value and chemical components of MRPM vary with raw materials (necks, backs, frames and skin) used in its production [Navarro, 2005].

Crushing of the bones and subsequent mechanical separation leads to changes in the chemical, physical, sensory and functional properties of the meat [Kanner, 1994; Abdullah \& Al-Najdawi, 2005] including the development of undesirable aromas (rancidity), loss of its characteristic red color because of lipid and pigments oxidation, loss or modification of the muscle fiber structure, reduced stability during storage as well as the functionality and processing ability [Mielnik et al., 2002; Bodner \& Sieg, 2009]. Quality loss can also result from the redistribution of the higher initial microbial load which favors the growth of microorganisms which make it highly perishable raw material [Gill, 1988]. Moreover, consumer's defense groups are concerned about the inclusion of bone fragments in the mechanically recovered meat [Froning, 1981], where mechanical separation results in some bone particles $(\varnothing<0.5 \mathrm{~mm})$ remaining in the meat mass [EU Regulation 2074/2005].

Brazilian legislation allows a maximum of $20 \%$ of total fresh 
cessed meat products [Brasil, 1981]. However, no Egyptian limit exist to regulate the usage of MRPM in meat industry resulting in products of low quality and has bad health impact on consumer, therefore the present study was designed to determine the effect of the addition of MRPM in commercial and experimentally processed traditional Egyptian luncheon using technical properties as well as chemical, histological methods.

\section{MATERIALS AND METHODS}

\section{Market samples}

A total of 40 beef luncheon samples (emulsion type sausage) produced by eight different meat processing plants (five samples each) were collected from different production lots. Each sample was represented by three packages from the same production date. Samples were immediately transferred to the laboratory of Food Hygiene Department, Faculty of Veterinary Medicine, Cairo University, then kept at $4^{\circ} \mathrm{C}$ till investigation.

\section{Experimental samples}

Six trials based experiment (three replicates each) was performed to produce traditional Egyptian luncheon sausage with different MRPM percentage and cooking core temperature. For production of beef luncheon sausage, six different meat batters were produced following the Good Manufacturing Practices guidelines. The control batter was produced with $70 \%$ beef meat, $1.8 \%$ sodium chloride, $0.3 \%$ ppm polyphosphates, 100 ppm sodium nitrite, $10 \%$ corn starch, and $7.5 \%$ added water. The other five meat batters were produced similar to the control, with replacement of beef meat with different percentages of MRPM (10, 30, 50, 70 and 90\%). All the prepared batters were filled in polyamide casing using piston filler and cooked using humid cooking program to three different core temperatures $\left(70,80\right.$ and $\left.90^{\circ} \mathrm{C}\right)$. Then cooled and kept in a refrigerator at $4^{\circ} \mathrm{C}$ till investigation.

All samples were examined for technological properties (texture and binding), ash, collagen, calcium, bone and cartilage contents, as well as subjected to histological examination.

\section{Technological evaluation (texture and binding)}

Texture and binding properties were examined by 12 panelists from the Department of Food Hygiene and Control, Faculty of Veterinary Medicine, Cairo University, using a 9-point scale according to [AMSA, 1995], where 9 denotes extremely acceptable and 1 denotes extremely unacceptable product. Prior to the analysis, panelists were trained in the definition and terms.

\section{Determination of ash, soluble and insoluble collagen and calcium content}

Ash content of luncheon samples was determined according to AOAC [1995]. Collagen was estimated according to Neuman \& Logan [1950] and Mahendrakar et al. [1988]. Absorbance of the test samples was measured at $540 \mathrm{~nm}$ against the blank using Unico (1200 Series, USA) spectrophotometer. The calculation for estimating hydroxyproline $(\mathrm{g} / 100 \mathrm{~g})$ in meat was outlined by Woessner [1961]. While calcium (Ca) content was estimated as $\mu \mathrm{g} / \mathrm{w} / \mathrm{w}$ according to Kingston \& Jassie [1988] using atomic absorption spectrometer (Ther- moscientic ICE 3000series, England) supplemented with deuterium background. Samples were first digested with pure nitric acid under high pressure and temperature by microwave sample preparation lab station (MLS-1200 MEGA).

\section{Morphological staining of bone and cartilage}

Staining of bone and cartilage was done according to Branscheid et al. [2009] using different solutions (Solution I: 0.1 g Alizarin Red S (C.I. 58005, Chroma) + 100 mL 95\% ethanol, Solution II: 0.3 g Alcian Blue 8 Gs (C.I. 74240, Serva) + $100 \mathrm{~mL} 70 \%$ ethanol, Solution III: $10 \mathrm{~mL}$ solution I + $10 \mathrm{~mL}$ Solution II $+10 \mathrm{~mL}$ glacial acetic acid $+170 \mathrm{~mL} \mathrm{70 \%} \mathrm{etha-}$ nol and Solution IV (Pre-staining rinsing solution): $100 \mathrm{~mL}$ $70 \%$ ethanol $+5 \mathrm{~mL}$ glacial acetic acid). Particles obtained from $70 \%$ ethanol were weighed, presorted by hand onto blotting paper after which differentiating bone (red) and cartilage (blue) particles were weighed separately. For documentation, the stained particles were carefully isolated, inspected under phase contrast microscopy (Zeiss Stemi 2000-C) and photographed using Zeiss MC 80DX camera.

\section{Histological analysis}

Duplicate $1 \times 1 \times 1 \mathrm{~cm}$ blocks from all investigated samples were fixed in $10 \%$ formol saline for $24 \mathrm{~h}$. Fixed samples were washed under tap water followed by dehydration using serial dilutions of alcohol (methyl, ethyl and absolute ethyl), then cleared in xylene and embedded in paraffin at $56^{\circ} \mathrm{C}$ in hot air oven for $24 \mathrm{~h}$. Paraffin bees wax tissue blocks were prepared for sectioning at 4 microns by slide microtome. The obtained tissue sections were collected on glass slides, deparaffinized and stained either by hematoxylin and eosin (H \& E) [Banchroft et al., 1996] or by trichrome blue [Official Standard, 1989] for histological examination.

\section{Statistical analysis}

The values given in each treatment category are the mean values from three replicate. Mean \pm standard errors (SE) were calculated. Data were subjected to analysis of variance (ANOVA). Comparison of means was carried out by Duncan's multiple-range test and significance was considered at $\mathrm{p}<0.05$. Analysis was performed using a SPSS package (SPSS 19.0 for Windows, SPSS Inc, Chicago, IL, USA).

\section{RESULTS}

\section{Marketed samples}

The results of technological evaluation (texture and binding properties), ash, collagen, calcium, bone and cartilage content of the marketed samples were represented in Table 1. It was noticeable that the scores of texture and binding properties ranged from 1.00 to 2.1 and from 1 to 2.33 , respectively, which indicated low overall acceptability of the products. Rough texture was detected in all examined samples together with cracks seen in luncheon slices during rolling. The ash content ranged from 2.9 to $3.7 \%$ with mean value of $3.4 \%$. Collagen content varied greatly among the examined samples as it ranged from 0.2 to $1.22 \%$ with $0.4 \%$ as a mean value, while Ca content ranged from 341.16 to $2756.25 \mu \mathrm{g} / \mathrm{g}$ with a mean value of $1063.00 \mu \mathrm{g} / \mathrm{g}$. 
TABLE 1. Mean values of texture and binding properties and chemical composition of marketed samples (mean \pm SD).

\begin{tabular}{lccccc|c|c|c}
\hline Industry name & Texture & Binding & $\begin{array}{c}\text { Ash } \\
(\%)\end{array}$ & $\begin{array}{c}\text { Collagen } \\
(\%)\end{array}$ & $\begin{array}{c}\text { Calcium } \\
(\mu \mathrm{g} / \mathrm{g} \text { wet weight })\end{array}$ & $\begin{array}{c}\text { Bone } \\
(\%)\end{array}$ & $\begin{array}{c}\text { Cartilage } \\
(\%)\end{array}$ \\
\hline I & $2.00^{\mathrm{a}} \pm 0.20$ & $1.50^{\mathrm{a}, \mathrm{b}} \pm 0.40$ & $3.00^{\mathrm{a}, \mathrm{b}} \pm 0.09$ & $0.200^{\mathrm{a}, \mathrm{b}} \pm 0.01$ & $358.31^{\mathrm{a}} \pm 68.27$ & $0.23^{\mathrm{a}, \mathrm{b}} \pm 0.01$ & $0.00^{\mathrm{a}} \pm 0.00$ \\
II & $1.73^{\mathrm{a}, \mathrm{b}} \pm 0.30$ & $1.60^{\mathrm{a}, \mathrm{b}} \pm 0.40$ & $3.12^{\mathrm{a}, \mathrm{b}, \mathrm{c}} \pm 0.07$ & $0.21^{\mathrm{a}, \mathrm{b}} \pm 0.10$ & $362.18^{\mathrm{a}} \pm 19.87$ & $0.00^{\mathrm{a}} \pm 0.00$ & $0.31^{\mathrm{a}, \mathrm{b}} \pm 0.01$ \\
III & $2.10^{\mathrm{a}} \pm 0.25$ & $2.33^{\mathrm{a}} \pm 0.40$ & $2.88^{\mathrm{b}} \pm 0.22$ & $0.51^{\mathrm{c}} \pm 0.12$ & $341.16^{\mathrm{a}} \pm 27.09$ & $0.00^{\mathrm{a}} \pm 0.00$ & $0.10^{\mathrm{a}} \pm 0.01$ \\
IV & $1.73^{\mathrm{a}, \mathrm{b}} \pm 0.20$ & $1.50^{\mathrm{a}, \mathrm{b}} \pm 0.20$ & $3.34^{\mathrm{c}, \mathrm{e}} \pm 0.09$ & $0.24^{\mathrm{a}, \mathrm{b}} \pm 0.04$ & $536.55^{\mathrm{a}} \pm 13.00$ & $0.10^{\mathrm{a}, \mathrm{b}} \pm 0.06$ & $0.29^{\mathrm{a}} \pm 0.01$ \\
V & $1.13^{\mathrm{c}} \pm 0.10$ & $1.00^{\mathrm{b}} \pm 0.00$ & $3.66^{\mathrm{d}, \mathrm{e}} \pm 0.06$ & $0.41^{\mathrm{a}, \mathrm{c}} \pm 0.20$ & $1457.29^{\mathrm{b}} \pm 52.71$ & $0.14^{\mathrm{a}, \mathrm{b}} \pm 0.01$ & $0.39^{\mathrm{a}, \mathrm{b}} \pm 0.01$ \\
VI & $1.30^{\mathrm{b}, \mathrm{c}} \pm 0.20$ & $1.70^{\mathrm{a}, \mathrm{b}} \pm 0.52$ & $3.64^{\mathrm{d}, \mathrm{e}} \pm 0.09$ & $1.22^{\mathrm{d}} \pm 0.04$ & $1309.08^{\mathrm{b}} \pm 88.61$ & $0.22^{\mathrm{a}, \mathrm{b}} \pm 0.01$ & $0.39^{\mathrm{a}, \mathrm{b}} \pm 0.01$ \\
VII & $1.00^{\mathrm{c}} \pm 0.00$ & $1.00^{\mathrm{b}} \pm 0.00$ & $3.48^{\mathrm{d}, \mathrm{e}} \pm 0.14$ & $0.20^{\mathrm{a}, \mathrm{b}} \pm 0.10$ & $1383.19^{\mathrm{b}} \pm 88.61$ & $0.34^{\mathrm{b}} \pm 0.01$ & $0.27^{\mathrm{a}} \pm 0.01$ \\
VIII & $1.00^{\mathrm{c}} \pm 0.00$ & $1.00^{\mathrm{b}} \pm 0.00$ & $3.73^{\mathrm{d}} \pm 0.07$ & $0.20^{\mathrm{b}} \pm 0.02$ & $2756.25^{\mathrm{c}} \pm 133.29$ & $0.19^{\mathrm{a}, \mathrm{b}} \pm 0.01$ & $0.85^{\mathrm{b}} \pm 0.01$ \\
\hline Mean & $1.50 \pm 0.10$ & $1.44 \pm 0.12$ & $3.40 \pm 0.10$ & $0.40 \pm 0.10$ & $1063.00 \pm 187.52$ & $0.15 \pm 0.02$ & $0.32 \pm 0.49$ \\
\hline
\end{tabular}

a-d: Means with different superscript within the same column differ significantly at $\mathrm{p}<0.05$.
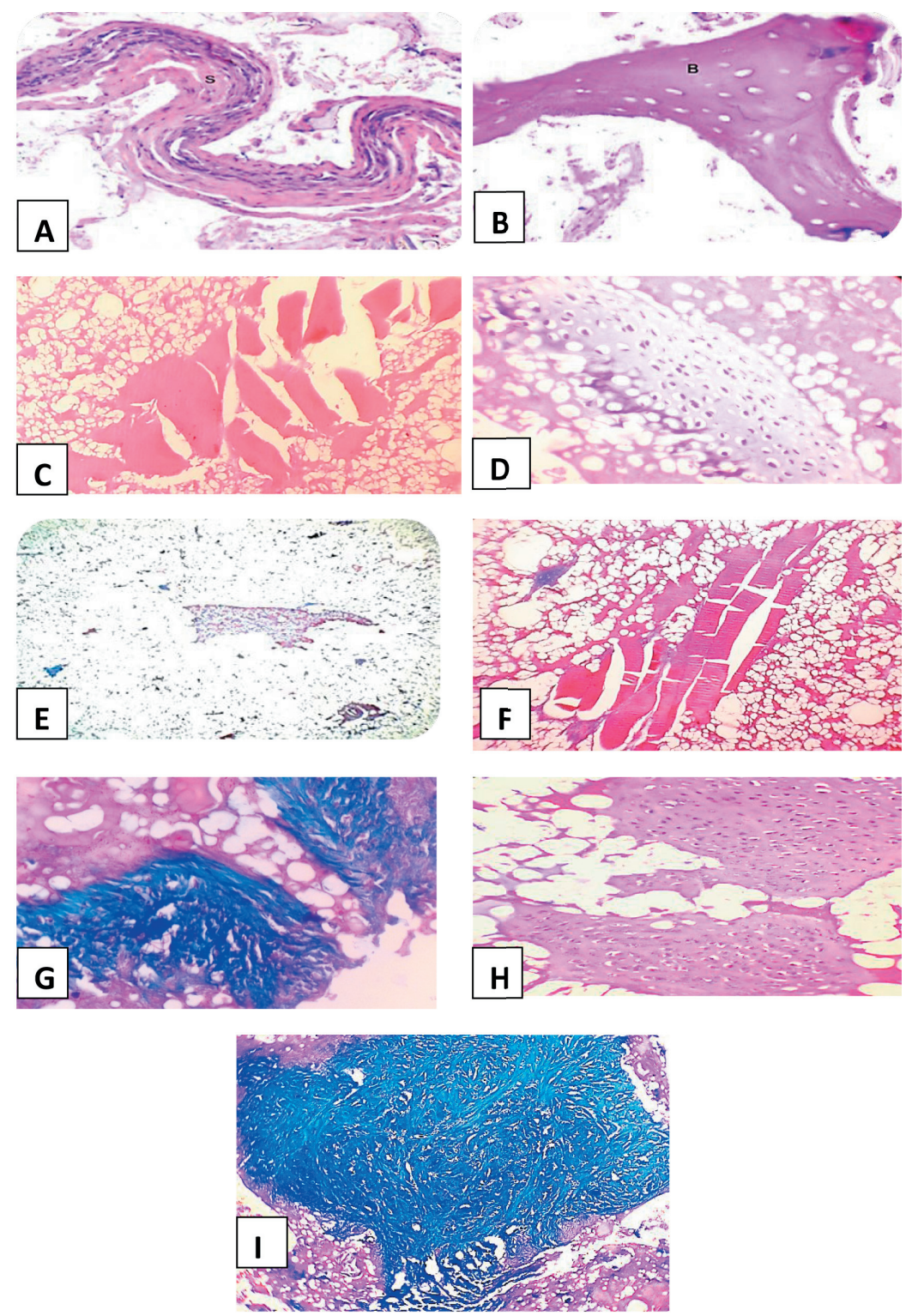

FIGURE 1. Histological sections stained with H\&E (A:E) and Trichrome blue (F:K).

(A) skin; (B) bone of marketed luncheon; (C) experimental control luncheon muscle; (D) 70\% MRPM experimental luncheon cartilage; (E) market samples cartilage and conective tissue; (F) experimental control luncheon muscle; (G) 70\% MRPM experimental luncheon conective tissue; (H) 90\% MRPM experimental luncheon bone; and (I) 90\% MRPM experimental luncheon conective tissue. 
TABLE 2. Chemical composition of raw materials (beef and mechanically recovered poultry meat) used for production of luncheon (mean \pm SD).

\begin{tabular}{l|c|c|c|c|c|c}
\hline & \multicolumn{2}{|c}{ Mechanically Recovered Poultry meat } & \multicolumn{3}{c}{ Meat } \\
\cline { 2 - 7 } & Min & Max & Mean & Min & Max & Mean \\
\hline Ash (\%) & 1 & 1.2 & $1.13 \pm 0.50$ & 0.52 & 1.32 & $0.87 \pm 0.04$ \\
Collagen (\%) & 0.89 & 1.00 & $0.96 \pm 0.55$ & 0.30 & 1.01 & $0.63 \pm 1.15$ \\
Ca $(\mu \mathrm{g} / \mathrm{g})$ & 1998.88 & 2558.031 & $2223.10 \pm 133.30$ & 201.70 & 290.00 & $245.66 \pm 23.0$ \\
Bone $(\%)$ & 0.09 & 0.54 & $0.31 \pm 0.60$ & & ND & ND \\
Cartilage $(\%)$ & 0.11 & 0.55 & $0.37 \pm 0.60$ & ND & & \\
\hline
\end{tabular}

ND: not detected

TABLE 3. Mean value of technological properties of experimental samples (mean $\pm \mathrm{SD}$ ).

\begin{tabular}{l|c|c|c|c|cc|c}
\hline \multirow{2}{*}{ Samples } & \multicolumn{3}{|c|}{ Texture } & \multicolumn{3}{c}{ Binding } \\
\cline { 2 - 7 } & $70^{\circ} \mathrm{C}$ & $80^{\circ} \mathrm{C}$ & $90^{\circ} \mathrm{C}$ & $70^{\circ} \mathrm{C}$ & $80^{\circ} \mathrm{C}$ & $90^{\circ} \mathrm{C}$ \\
\hline Control & $8.00^{\mathrm{a}, \mathrm{A}} \pm 0.58$ & $9.00^{\mathrm{a}, \mathrm{A}} \pm 0.58$ & $9.00^{\mathrm{a}, \mathrm{A}} \pm 0.58$ & $9.00^{\mathrm{a}, \mathrm{A}} \pm 0.58$ & $9.00^{\mathrm{a}, \mathrm{A}} \pm 0.58$ & $9.00^{\mathrm{a}, \mathrm{A}} \pm 0.58$ \\
$10 \%$ MRM & $6.75^{\mathrm{a}, \mathrm{b}, \mathrm{A}} \pm 0.58$ & $7.77^{\mathrm{a}, \mathrm{b}, \mathrm{A}} \pm 0.58$ & $7.92^{\mathrm{a}, \mathrm{b}, \mathrm{A}} \pm 0.58$ & $7.83^{\mathrm{a}, \mathrm{b}, \mathrm{A}} \pm 0.58$ & $8.00^{\mathrm{a}, \mathrm{b}, \mathrm{A}} \pm 0.58$ & $8.80^{\mathrm{a}, \mathrm{A}} \pm 0.58$ \\
$30 \%$ MRM & $5.50^{\mathrm{b}, \mathrm{A}} \pm 0.58$ & $6.50^{\mathrm{b}, \mathrm{A}} \pm 0.58$ & $7.00^{\mathrm{b}, \mathrm{c}, \mathrm{A}} \pm 0.58$ & $6.83^{\mathrm{b}, \mathrm{A}} \pm 0.58$ & $7.75^{\mathrm{a}, \mathrm{b}, \mathrm{A}} \pm 0.58$ & $8.00^{\mathrm{a}, \mathrm{A}} \pm 0.58$ \\
$50 \%$ MRM & $3.70^{\mathrm{c}, \mathrm{A}} \pm 0.58$ & $3.80^{\mathrm{c}, \mathrm{A}} \pm 0.58$ & $5.90^{\mathrm{c}, \mathrm{B}} \pm 0.58$ & $6.50^{\mathrm{b}, \mathrm{A}} \pm 0.58$ & $7.00^{\mathrm{b}, \mathrm{A}} \pm 0.58$ & $8.00^{\mathrm{a}, \mathrm{A}} \pm 0.58$ \\
$70 \%$ MRM & $3.44^{\mathrm{c}, \mathrm{A}} \pm 0.58$ & $3.72^{\mathrm{c}, \mathrm{A}} \pm 0.58$ & $3.77^{\mathrm{d}, \mathrm{A}} \pm 0.58$ & $3.33^{\mathrm{c}, \mathrm{A}} \pm 0.58$ & $3.80^{\mathrm{c}, \mathrm{A}, \mathrm{B}} \pm 0.58$ & $5.33^{\mathrm{b}, \mathrm{B}} \pm 0.58$ \\
$90 \%$ MRM & $3.00^{\mathrm{c}, \mathrm{A}} \pm 0.58$ & $3.20^{\mathrm{c}, \mathrm{A}} \pm 0.58$ & $4.00^{\mathrm{d}, \mathrm{A}} \pm 0.58$ & $2.00^{\mathrm{c}, \mathrm{A}} \pm 0.58$ & $2.50^{\mathrm{c}, \mathrm{A}} \pm 0.58$ & $2.66^{\mathrm{c}, \mathrm{A}} \pm 0.58$ \\
\hline
\end{tabular}

a-d: Means with different superscript within the same column differ significantly for different concentration of MRPM at $p<0.05$. A,B: Means with different superscript within the same row differ significantly for heat treatment at $\mathrm{p}<0.05$.

Histological analyses of the marketed samples stained with H\&E showed great variability between the different processing plants especially in bone, cartilage and skin contents. Low content of muscular tissues with diffusely dispersed bone, cartilage tissues and high content of skin were evident in all samples (Figure 1, A and B). Moreover with Trichrome blue, the connective tissue content was more higher than the muscular tissue content in all marketed samples (Figure 1, E) where connective tissue appeared blue and muscular tissue appeared red.

\section{Experimental samples}

Results of chemical analysis, bone and cartilage of the raw materials used in the production of luncheon sausages (Table 2) showed that the mean values of ash, collagen, calcium were $1.13 \%, 0.96 \%, 2223.10 \mu \mathrm{g} / \mathrm{g}$ for MRPM and $0.87 \%$, $0.63 \%, 245.66 \mu \mathrm{g} / \mathrm{g}$ for beef, respectively. Bone and cartilage contents of MRPM were 0.31 and $0.37 \%$ respectively, whereas both bone and cartilage particles were not detected in beef.

Technological properties (texture and binding) of experimental luncheon samples were presented in Table 3 . The level of MRPM significantly $(\mathrm{p}<0.05)$ affected texture and binding properties of luncheon sausages immediately after processing. It was clear that increasing the addition of MRPM in luncheon formulations from $30 \%$ to $90 \%$ caused significant reduction in the texture score compared with the control and 10\% MRPM group. The product with 50\% MRPM had unacceptable scores for both texture (3.70 and 3.80 at $70^{\circ} \mathrm{C}$ and $80^{\circ} \mathrm{C}$, respectively) and binding $\left(3.33,3.80\right.$ at $70^{\circ} \mathrm{C}$ and $80^{\circ} \mathrm{C}$, respectively). Many panelists were able to detect bone and cartilage particles easily at 30-50\% MRPM (unpublished observation recorded by most of the panelists). Increasing cooking temperature of experimentally-produced luncheon sausages from $70^{\circ} \mathrm{C}$ to $90^{\circ} \mathrm{C}$ showed no difference ( $p>0.05)$ in texture scores in all formulations; except for 50\% MRPM incorporated sausage that showed significant improvement in texture score at cooking temperature at $90^{\circ} \mathrm{C}$. Moreover, addition of 10\% MRPM in luncheon formulation revealed no significant difference $(p>0.05)$ in texture score at all cooking temperatures compared with the control group. Regarding binding scores, no difference $(\mathrm{p}>0.05)$ could be proved among MRPM incorporated luncheon sausage cooked at different cooking temperature $\left(70^{\circ} \mathrm{C}, 80^{\circ} \mathrm{C}, 90^{\circ} \mathrm{C}\right)$ except for 70\% MRPM group which showed significant improvement in the binding score at $90^{\circ} \mathrm{C}$.

Ash, collagen, $\mathrm{Ca}$, bone and cartilage content of experimentally-produced luncheon were tabulated in Table 4 and Table 5. There was no ( $p>0.05)$ change in ash content of the luncheon with the addition of MRPM except in 90\% MRPM group at all cooking temperatures.

Increasing MRPM in experimentally-produced luncheon caused increase $(\mathrm{p}<0.05)$ in collagen, $\mathrm{Ca}$, bone and cartilage contents. Although the application of high temperature during cooking decreased significantly $(\mathrm{p}<0.05)$ collagen content, it did not affect $(\mathrm{p}>0.05)$ the $\mathrm{Ca}$, bone and cartilage contents. 


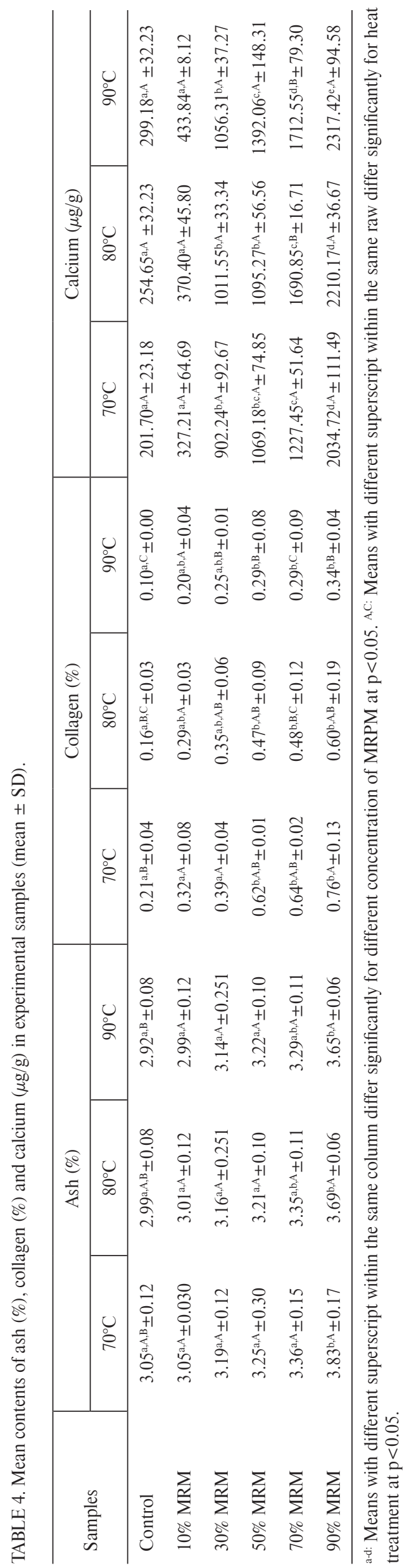

Regarding the histological examination, control luncheon sausages stained with $H \& E$ showed the presence of muscular tissue and adipose cells only (Figure 1, C). Muscular tissue, adipose cells with very few connective tissue, skin, cartilage comprised the largest part of luncheon sausage produced with 10\% MRPM. Connective tissue, skin, cartilage and bones comprised the largest part of the products produced with higher percentages of MRPM while the content of muscular tissue decreased. Moreover, the bone and cartilage contents increased proportionally with increasing percentage content of MRPM (Figure 1, D). Moreover, staining the samples with trichrome blue substantiated the results of $\mathrm{H} \& \mathrm{E}$ where control luncheon sausage showed the presence of high content of muscular tissue and low amount of connective tissue (Figure 1, F). Addition of MRPM increased the content of connective tissue (Figure 1, G) and cartilage as well as and decreased the content of muscular tissue (Figure 1, H and I). The product formulated with 90\% MRPM showed almost absence of muscular tissue with high content of connective tissue and cartilage (Figure 1, I).

\section{DISCUSSION}

The massive increase in poultry production worldwide, parallel to the change in consumers eating attitude from consumption of whole chicken to cuts and fillets, resulted in huge amounts of skin, frames and necks. Mechanical recovery process provides the magic utilization of these leftover materials [Froning, 1981; Dawson et al., 1988], with production of MRPM that has good nutritional and technological properties, which enhance its use in poultry and meat processing industry [Serdaroğlu et al., 2005]. Regulation of MRPM used in poultry and meat industry has been established in some countries [EU Regulation, 2005], while stays still unclear in Egypt. This encourages most of meat processors to use MRPM as an inexpensive material to substitute meat in poultry and meat products, with high percentage reached to total meat replacement [Emara, 2005] without any care to its health hazards to consumer or product quality and shelf life.

Scores of texture and binding properties of the marketed samples indicated low overall acceptability of the products. The rough texture of all samples could refer to the presence of bone particles in high amount as a result of using MRPM in the production of luncheon sausage. Also, the cracks found in luncheon slices indicated poor binding capacity of the product. This finding was confirmed by Field [1988] and Raphaelides et al. [1998], who found that meat products with over $30 \%$ of mechanically recovered meat had grainy texture, and the extent to which this occurs depends upon the size and amount of bone particles contained in the final meat product.

High ash and $\mathrm{Ca}$ contents are noticed in all marketed samples. Ash content exceeded the permissible limit stated by the Egyptian Standard Specification [ESS 1114/2005] which indicated high mineral content. This was referred to the addition of high amount of MRPM in the formulation of luncheon sausage, which could be correlated with high bone content in the examined samples [Field, 2000]. Also 
TABLE 5. Mean bone and cartilage contents of experimental samples (mean $\pm \mathrm{SD}$ ).

\begin{tabular}{l|c|c|c|c|c|c}
\hline \multirow{2}{*}{ Samples } & \multicolumn{3}{|c|}{ Bone (\%) } & \multicolumn{3}{c}{ Cartilage (\%) } \\
\cline { 2 - 7 } & $70^{\circ} \mathrm{C}$ & $80^{\circ} \mathrm{C}$ & $90^{\circ} \mathrm{C}$ & $70^{\circ} \mathrm{C}$ & $80^{\circ} \mathrm{C}$ & $90^{\circ} \mathrm{C}$ \\
\hline Control & $0.00^{\mathrm{a}, \mathrm{A}} \pm 0.00$ & $0.00^{\mathrm{a}, \mathrm{A}} \pm 0.00$ & $0.00^{\mathrm{a}, \mathrm{A}} \pm 0.00$ & $0.00^{\mathrm{a}, \mathrm{A}} \pm 0.00$ & $0.00^{\mathrm{a}, \mathrm{A}} \pm 0.00$ & $0.00^{\mathrm{a}, \mathrm{A}} \pm 0.00$ \\
$10 \%$ MRM & $0.00^{\mathrm{a}, \mathrm{A}} \pm 0.00$ & $0.00^{\mathrm{a}, \mathrm{A}} \pm 0.00$ & $0.00^{\mathrm{a}, \mathrm{A}} \pm 0.00$ & $0.16^{\mathrm{a}, \mathrm{A}} \pm 0.01$ & $0.16^{\mathrm{b}, \mathrm{A}} \pm 0.01$ & $0.00^{\mathrm{a}, \mathrm{B}} \pm 0.00$ \\
$30 \%$ MRM & $0.00^{\mathrm{a}, \mathrm{A}} \pm 0.00$ & $0.00^{\mathrm{a}, \mathrm{A}} \pm 0.00$ & $0.00^{\mathrm{a}, \mathrm{A}} \pm 0.00$ & $0.35^{\mathrm{a}, \mathrm{b}, \mathrm{A}} \pm 0.01$ & $0.31^{\mathrm{c}, \mathrm{B}} \pm 0.01$ & $0.07^{\mathrm{b}, \mathrm{C}} \pm 0.01$ \\
$50 \%$ MRM & $0.51^{\mathrm{a}, \mathrm{b}, \mathrm{A}} \pm 0.01$ & $0.37^{\mathrm{b}, \mathrm{B}} \pm 0.01$ & $0.27^{\mathrm{b}, \mathrm{C}} \pm 0.01$ & $0.44^{\mathrm{a}, \mathrm{b}, \mathrm{A}} \pm 0.01$ & $0.38^{\mathrm{d}, \mathrm{B}} \pm 0.01$ & $0.10^{\mathrm{c}, \mathrm{C} \pm 0.00}$ \\
$70 \%$ MRM & $0.58^{\mathrm{a}, \mathrm{b}, \mathrm{A}} \pm 0.01$ & $0.46^{\mathrm{c}, \mathrm{B}} \pm 0.01$ & $0.27^{\mathrm{b}, \mathrm{C}} \pm 0.01$ & $0.52^{\mathrm{a}, \mathrm{b}, \mathrm{A}} \pm 0.01$ & $0.33^{\mathrm{e}, \mathrm{B}} \pm 0.01$ & $0.14^{\mathrm{d}, \mathrm{C}} \pm 0.00$ \\
$90 \%$ MRM & $1.04^{\mathrm{b}, \mathrm{A}} \pm 0.58$ & $0.54^{\mathrm{d}, \mathrm{A}} \pm 0.01$ & $0.44^{\mathrm{c}, \mathrm{A}} \pm 0.01$ & $1.02^{\mathrm{b}, \mathrm{A}} \pm 0.58$ & $0.51^{\mathrm{f}, \mathrm{A}} \pm 0.01$ & $0.22^{\mathrm{e}, \mathrm{A}} \pm 0.00$ \\
\hline
\end{tabular}

a-d: Means with different superscript within the same column differ significantly for different concentration of MRPM at $p<0.05$. A-C: Means with different superscript within the same raw differ significantly for heat treatment at $\mathrm{p}<0.05$.

the high collagen content of luncheon sausages (Table 4) indicates that MRPM are incorporated in luncheon formulation, moreover it may contain high amount of skin and bone [Abdullah \& Al-Najdawi, 2005]. The wide variation in ash and collagen content (Table 1) among samples from different processing plants may result from different quantity and quality of MRPM used in production of luncheon sausage. Chemical composition of MRPM depends on many factors as breed, age of animal, origin of the material used and the mix of raw materials subjected to deboning [Navarro, 2005], as well as settings and type of deboner used for the mechanical separation [Henckel et al., 2004]. Salman [1995] reported that MRPM had lower moisture and protein but higher fat and ash contents than the manually recovered meat.

Although the application of high temperatures during processing of luncheon sausage significantly $(p<0.05)$ lowered collagen content, due to the conversion of collagen in the product into soluble gelatin [Pearson \& Gillett, 1999]. On the other hand, $\mathrm{Ca}$ content was unaffected $(\mathrm{p}>0.05)$ by different cooking temperatures. These results were in harmony with that reported by Seiquer et al. [2010].

The presence of bone and cartilage particles is one of the most important physical hazards. Most of marketed samples contain both bone and cartilage, which indicates that most processors use high amounts of MRPM in luncheon production. Numerous approaches have been employed to differentiate mechanically recovered poultry meat from hand recovered meat by presence of bone [Pickering et al., 1995; Beraquet, 2000; Field, 2000; Hildebrandt et al., 2006; Branscheid et al., 2009].

The obtained photomicrographs in the present study (Figure1) met the observation of Anon [2006] and Branscheid [2007] that standard histological examination is one of the methods used for quality control of meat products in general, and for the detection of MRPM in particular.

\section{CONCLUSION}

Incorporation of MRPM in Egyptian luncheon adversely affected its chemical composition and quality attributes, so the detection of MRPM in emulsion type products is very important. Addition of $10 \%$ MRPM to luncheon formulation could not be detected through technological properties, chemical composition or histological section at different cooking temperature. While use of $30 \%$ or more MRPM could be correlated well with low texture, binding, high calcium and ash content, presence of bone and cartilage. Also, histological technique with $\mathrm{H} \& \mathrm{E}$ and trichrome blue stain can be used as a safe and accurate method for detection of adulteration of meat emulsion products.

\section{ACKNOWLEDGEMENTS}

The authors would like to acknowledge Faculty of Veterinary Medicine, Cairo University and National Center for Radiation Research and Technology (NCRRT) for all the facilities offered.

\section{REFERENCES}

1. Abdullah B., Al-Najdawi R., Functional and sensory properties of chicken meat from spent-hen carcasses deboned manually or mechanically in Jordan. Int. J. Food Sci. Technol., 2005, 40, 537-543.

2. AMSA, American Meat Science Association. 1995, Research guidelines for cookery, sensory evaluation and instrumental tenderness measurements of fresh meat. Chicago, IL, USA: American Meat Science Association.

3. Anonymous, Bestimmung der geweblichenZusammensetzung von Fleisch, Fleischerzeugnissen und Wurstwaren. Routineverfahren zur qualitativen und quantitative histologischen Untersuchung. 2006, in: Bundesamt für Verbraucherschutz und Lebensmittelsicherheit, Amtliche Sammlung von Untersuchungsverfahren nach § 64 LFGB, § 35 Vorlufiges Tabakgesetz, § 28b GenTG. 1 (2, 06.13): 1-14. Berlin, Wien, Züric: Beuth.

4. AOAC, Association of Official Analytical Chemists, Official Methods of Analysis. 1995, Association of Official Analytical Chemists, $16^{\text {th }}$ ed., Washington, DC, USA.

5. Banchroft J.D., Stevens A., Turner D.R., Theory and Practice of Histological Techniques, $4^{\text {th }}$ Ed., 1996, Churchill Livingstone, New York, London, San Francisco, Tokyo.

6. Benitez B., Archile A., Rangel L., Bracho M., Hernandez M., Marquez E., Nutritional quality and acceptability of a product 
formulated with mechanically deboned poultry meat, plasma and bovine red cell. Arch. Latinoam. Nutr., 2002, 52, 307-312.

7. Beraquet N.J., Carne mecanicamenteseparada de aves. 2000, in: Seminário e CursoTeórico-Prático "Agregando Valor à Carne de Aves", 2000, Campinas. Campinas: CTC (in Italian).

8. Bodner J.M., Sieg J., Fiber. 2009, in: Ingredients In Meat Products (ed. R. Tarté). Springer Science, Business Media, LLC, pp. 83-109.

9. Branscheid W., Histologische Untersuchung von Fleischerzeugnissen mit Gemengecharakter, 2007, in: Qualität von Fleisch und Fleischwaren, Vol. 2 (eds. W. Branscheid, K.O. Honikel, G.v. Lengerken, K. Troeger). Deutscher Fachverlag, Frankfurt, pp. 907-916.

10. Branscheid W., Judas M., Höreth R.H., The morphological detection of bone and cartilage particles in mechanically separated meat. Meat Sci., 2009, 81, 46-50.

11. Brasil, Ministério da Agricultura. Divis ao de Inspeção de carnes e derivados.Servicço de Inspeçao de Produtos de Origem Animal - Regulamento da Inspeçsimao Industrial e Sanitãria dos Produtos de Origem Animal.Brasǐlia: Ministério da Agricultura, 1981, Circular 28/ DICAR.

12. Dawson P.L., Sheldon B.W., Ball H.R., Extraction of lipid and pigment components from mechanically deboned chicken meat. J. Food Sci., 1988, 53, 1615-1617.

13. Dingman S.E., May S.G., Smithey S.L., Meat Emulsion Product. United States Patent, 2002, 1, 10.

14. Emara M.M.T., Use of chlorine, benzoate and lactic acid as decontaminators to mechanically separated poultry meat and application in traditional Egyptian luncheon. Vet. Med. J. Giza, 2005, 53 (1), 153-162.

15. ESS 2005/1114: Egyptian Standard Specification for Traditional Egyptian luncheon (beef luncheon). Published and updated by Egyptian Standard organization for specification.

16. EU Regulation, Commission regulation (EC) No 2074/2005. Official J. European Union. L 338/27, 2005.

17. Field R.A., Mechanically separated meat, poultry and fish. 1988, in: Edible Meat By-Products (eds. A.M. Pearson, T.R. Dutson). Elsevier Applied Science, New York, pp. 83-128.

18. Field R.A., Ash and calcium as measures of bone in meat and bone mixture. Meat Sci., 2000, 55, 255-264.

19. Field R.A., Mechanically recovered meat. 2004, in: Encyclopedia of Meat Sciences. Academic Press, San Diego, CA.

20. Froning G.W., Mechanical deboning of poultry and fish. 1981, in: Advances in Food Research (eds. C.O. Chichester, E.M. Mark, G.F. Stewart). Academic Press, London, pp. 109-147.

21. Gill C.O., Microbiology of edible meat by products. 1988, in: Edible Meat By-Products (eds. A.M. Pearson, T.R. Dutson). Elsevier Applied Science. Barking, pp. 47-82.

22. Henckel P., Vyberg M., Thode S., Hermansen S., Assessing the quality of mechanically and manually recovered chicken meat. LWT - Food Sci. Technol., 2004, 37, 593-601.

23. Hildebrandt G., Raucher K., Stenzel W.R., Analysen merkmale zum Nachweis von Separatorenfleisch 2 MikroskopischeUntersuchung. Fleischwirtschaft, 2006, 86, 111-114 (in German).
24. Kanner J., Oxidative processes in meat and meat products: Quality Implications. Meat Sci., 1994, 36, 169-189.

25. Kingston H.M., Jassie L.B., Introduction to Microwave Sample Preparation. 1988, ASC.Professional Reference Book. Washington, DC. U.S.A.

26. Mahendrakar N.S., Dani N.P., Ramesh B.S., Amla B.L., Effect of post-mortem conditioning treatments to sheep carcasses on some biophysical characteristics of muscles. J. Food Sci. Technol., 1988, 25, 340-344.

27. Mielnik M.B., Aaby K., Rolfsen K., Ellejaer M.R., Nilsson A., Quality of comminuted sausages formulated from mechanically deboned poultry meat. Meat Sci., 2002, 61, 73-84.

28. Navarro C., Optimizaci'on del procesos de obtenci'on de gelesc 'arnicospartir de carne de avemec 'anicamenterecuperada, 2005. Ph.D. Dissertation, Universidad Miguel Hern`andez, Elche, Spain.

29. Neuman R.E., Logan M.A., Determination of hydroxyproline content. J. Biol. Chem., 1950, 184, 299-306.

30. Official Standard, 1989, Amtliche Sammlung von Untersuchungsverfahren nach § 64 LFGB, Bestimmung der geweblichen. Zusammensetzung von Fleisch, Fleischerzeugnissen und Wurstwaren L 06.00.13, Berlin: Beuth Verlag. p. 14.

31. Pearson A.M., Gillett T.A., Sausages. Processed Meats. 1999, Aspen Publishers Inc., Gaithersburg, Maryland, pp. 210-241.

32. Pickering K., Evans C.L., Hargin K.D., Stewart C.A., Investigation of methods to detect mechanically recovered meat in meat products. III: Microscopy. Meat Sci., 1995, 40, 319-326.

33. Raphaelides S.N., Grigoropoulou S., Petridis D., Quality attribute of pariza salami as influenced by the addition of mechanically deboned chicken meat. Food Qual. Pref., 1998, 9, 237-242.

34. Salman H.K., Aqueous processing influences on composition and functionality of mechanically separated broiler meat. 1995. Ph.D. Dissertation, Louisiana State University and Agricultural and Mechanical College.

35. Seiquer I., Delgado-Andrade C., Haro A., Navarro M.P., Assessing the effects of severe heat treatment of milk on calcium bioavailability: in vitro and in vivo studies. J. Dairy Sci., 2010, 93, 5635-5643.

36. Serdaroğlu M., Turp G.Y., Bağdatlioğlu N., Effects of deboning methods on chemical composition and some properties of beef and turkey meat. Turk. J. Vet. Anim. Sci., 2005, 29, 797-802.

37. Tyburcy A., Toszek E., Cegiełka A., The comparison between the raw material composition of chemical characteristics of poultry and pork frankfurters offered for retail sales on the Warsaw market. Zywność. Nauka. Technologia. Jakość, 2005, 3(44), 105-112 (in Polish).

38. Woessner J.F., The determination of hydroxyproline in the tissue and protein samples containing small proportions of amino acid. Arch. Biochem. Bioph., 1961, 93, 440-442.

Submitted: 25 August 2014. Revised: 24 November 2014. Accepted 5 December 2014. Published on-line: 25 November 2015. 
